JURNAL PENDIDIKAN, p-ISSN 2715-095X, e-ISSN 2686-5041

Volume 30, No.1, Maret 2021 (13-22)

Online: http://journal.univetbantara.ac.id/index.php/jp

\title{
Penerapan Metode Mind Mapping Berbasis Daring Untuk Meningkatkan Hasil Belajar Mahasiswa PGSD di Masa Pandemi Covid-19
}

\author{
Sarah Nurhabibah \\ Program Studi Pendidikan Guru Sekolah Dasar Universitas Nusa Cendana, Kupang NTT \\ Email: sarahnurhabibah1994@gmail.com
}

\begin{abstract}
Abstrak: Metode PTK pada penelitian ini bertujuan untuk mengetahui peningkatan hasil belajar ranah kognitif mahasiswa program studi PGSD Universitas Nusa Cendana (UNDANA) dalam mata kuliah Keterampilan Berbahasa Indonesia dengan diterapkannya metode mind mapping berbasis daring di masa pandemic Covid-19. Terdapat dua siklus tindakan dalam penelitian ini dengan subjek penelitian ialah mahasiswa kelas IIIE berjumlah 48 orang. Analisis data diolah secara kuantitatif serta kualitatif. Di siklus I setelah diaplikasikan metode mind mapping berbasis daring dari 48 mahasiswa ditemukan data nilai hasil belajar ranah kognitif mahasiswa nilai rata-ratanya mencapai 75,26 kriteria baik. Pada siklus II nilai rata-rata hasil belajar mahasiswa di ranah kognitifnya meningkat sebesar 83 dikategorikan sangat baik. Hasil penelitian menunjukkan bahwa penerapan metode mind mapping berbasis daring mampu meningkatkan hasil belajar kognitif mahasiswa PGSD UNDANA di masa pandemi Covid-19 dalam mata kuliah Keterampilan Berbahasa Indonesia.
\end{abstract}

Kata-kata Kunci: Mind mapping, hasil belajar kognitif, mahasiswa PGSD.

\section{Application of the Online-Based Mind Mapping Method to Improve Learning Outcomes of PGSD Students Daring the Covid-19 Pandemic}

\begin{abstract}
Sarah Nurhabibah
Elementary School Teacher Education Study Program, University of Nusa Cendana, Kupang, NTT

Email: sarahnurhabibah1994@gmail.com

Abstract: The PTK method in this study aims to see the improvement of learning outcomes in the cognitive domain of students of the PGSD Nusa Cendana University (UNDANA) study program in the Indonesian Language Skills course by applying the online-based mind mapping method during the Covid-19 pandemic. The activity of the two cycles of action in this study with the research subjects being class III students assessing 48 people. Quantitative and qualitative data analysis. In the first cycle, after the application of the mind mapping method based on the courage of the 48 students, it was found that the data on the learning outcomes of the students' cognitive domain mean 75.26 good criteria. In cycle II, the mean of student learning outcomes in the cognitive domain increased by 83 categorized as very good. The results showed that the application of the online-based mind mapping method was able to improve the cognitive learning outcomes of PGSD UNDANA students during the Covid-19 pandemic in the Indonesian Language Skills course.
\end{abstract}

Key words: Mind mapping, cognitive learning outcomes, PGSD students 


\section{Pendahuluan}

Di masa pandemi Covid-19 ini perkuliahan harus tetap terlaksana dengan cara study from home dengan memanfatkan pembelajaran teknologi informasi dan komunikasi/pembelajaran daring. Indrayana dan Sadikin (2020) menjelaskan melalui penerapan pembelajaran daring selain bisa mencegah penularan Covid-19 di kampus, pembelajaran daring ini juga dapat memudahkan mahasiswa dalam mengikuti perkuliahan selama pandemi Covid-19. Berdasarkan pengamatan dalam pelaksanaan pembelajaran daring ini masih terdapat permasalahan yang terdiri atas: 1) hasil belajar mahasiswa di ranah kognitif dalam mata kuliah Keterampilan Berbahasa Indonesia masih rendah, terlihat kategori nilai rata-rata pretest dari 48 mahasiswa yang dikategorikan cukup persentasenya sebesar $62,5 \%$ serta nilai rata-rata pretest 62,06 2) mahasiswa terlihat bosan dengan perkuliahan daring yang monoton, serta 3) mahasiswa kesulitan untuk memahami materi yang disampaikan dosen. Hal ini mengakibatkan rendahnya hasil belajar mahasiswa. Agar hasil belajar kognitif mahasiswa dapat meningkat, upaya yang bisa dilakukan oleh dosen ialah dengan menerapkan metode mind mapping berbasis daring dalam mata kuliah Keterampilan Berbahasa Indonesia di masa pandemi Covid-19.

Metode pembelajaran adalah cara yang digunakan pendidik dalam mengadakan hubungan dengan siswa/mahasiswa pada saat pembelajaran (Sudjana, 2005), sedangkan menurut Zuhaerini, dkk. (1977) metode pembelajaran adalah salah satu komponen proses pembelajaran sebagai alat untuk mencapai tujuan dengan dukungan komponen pembelajaran lainnya yang merupakan satu kesatuan dalam sistem pendidikan. Metode adalah cara untuk mengimplementasikan rencana yang telah dibuat dalam kegiatan nyata agar tujuan pembelajaran dapat tercapai secara optimal (Sanjaya, 2006). Metode mind mapping ialah salah satu metode dalam metode pembelajaran quantum learning, yang termasuk pendekatan pembelajaran siswa aktif atau active learning. Menurut Deporter (2000) peta pikiran (mind map) meggunakan pengingat visual dan sensorik dalam suatu pola dari ide-ide yang berkaitan, seperti peta jalan yang dapat digunakan untuk mempermudah dalam belajar, mengorganisasikan, dan merencanakan. Buzan (2008) menjelaskan beberapa pengertian dari mind map sebagai berikut: 1) mind map ialah cara termudah untuk menempatkan informasi untuk diingat dan mengambil informasi itu ketika dibutuhkan, 2) mind map adalah cara mencatat yang efektif, kreatif, dan secara harfiah akan "memetakan" pikiran-pikiran, 3) mind map adalah hasil dari metode mind mapping ialah hasil visualisasi berupa simbol atau gambar, yang dapat digunakan sebagai ganti catatan tertulis dan hasilnya lebih mudah untuk diingat, 4) mind map adalah alat pikir organisasional yang sangat efektif. Mind mapping sangat bermanfaat untuk untuk penyampaian gagasan/presentasi terutama saat mahasiswa bekerja kelompok dan banyak pemikiran/ide gagasan yang ajukan (DePorter, 2001).

Pembuatan mind mapping dapat membantu mahasiswa dalam merencanakan/merancang proses pemecahan masalah. Dengan adanya pembuatan mind mapping mahasiswa memiliki langkah-langkah yang terarah untuk memecahkan masalah, sehingga dalam menyelesaikan masalah misalnya dalam merancang skripsinya kelak, mahasiswa sudah terbiasa dengan alur yang tergambar pada mind mapping yang telah dirancang. Mind mapping bisa membantu alur berpikir mahasiswa untuk menyelesaikan pemecahan permasalahan (Sabil, 2014). Menurut Komar dan Supriyono (2010) mind mapping dapat digunakan sebagai alat bantu dalam proses pembelajaran untuk meningkatkan minat, pemahaman konsep pembelajaran serta prestasi belajar siswa ataupun 
mahasiswa. Darmuki, et. al. (2019) menjelaskan metode mind mapping bisa membangkitkan minat belajar mahasiswa sehingga membuat mahasiswa tertarik serta antusias pada perkuliahan. Pemetaan pikiran yang telah disusun disajikan di depan kelas, untuk mengarahkan mahasiswa pada materi yang dipelajari dan mengidentifikasi informasi yang tidak relevan dengan materi. Garis besar materi yang terdapat dalam mind mapping dipelajari melalui diskusi dalam pembelajaran (Astriani, Susilo, Suwono, Lukiati, \& Purnomo, 2020). Untuk membuat mind mapping langkah-langkahnya menurut Zein (2015) terdiri atas: 1) Dimulai dari bagian tengah kertas kosong yang diletakkan dalam posisi memanjang dengan menuliskan central topik, biasanya judul bab serta usahkan berbentuk image/gambar. 2) Buatlah ide dasar utama/Basic Ordering Ideas-BOIs, biasanya ialah judul sub-bab yang dibuat dengan menggunakan SWH (what, why, where, when, serta how). 3) Melengkapi setiap BOIs dengan cabang-cabang berisi data pendukung. 4) Hubungkan cabang-cabang tingkat kedua serta ketiga pada tingkat pertama dan kedua, dan seterusnya. 5) Gunakan warna pada seluruh mind map. 6) Buatlah cabang-cabang mind map membentuk lengkungan/melengkung bukan garis lurus. 7) Gunakan satu kata kunci per baris, dan 8) Lengkapi setiap cabang dengan simbol, gambar, daftar kode, ataupun grafik.

Manfaat mind mapping menurut Siregar (2014) ialah, mempercepat pembelajaran, memudahkan melihat keterkaitan antar topik yang berbeda, membantu brainstorming, agar ide mengalir dengan mudah, melihat gambaran yang besar, memudahkan untuk mengingat, serta menyederhanakan struktur. Adapun keunggulan dari metode mind mapping menurut Buzan (2004) ialah terdiri atas 1) dapat dengan mudah ditulis dengan tangan atau menggunakan aplikasi/platform teknologi dari telefon genggam atau komputer, 2) Apapun materinya bisa dituangkan melalui metode mind mapping, 3) Penggunaannya sangat luas, mulai dari anak-anak sekolah, mahasiswa sampai direktur, 4) Paling lama di memori ingatan, 5) mengoptimalkan kerja fungsi otak kanan serta kiri secara penuh, dan 6) membantu untuk merencanakan, berkomunikasi, memusatkan perhatian, menyelesaikan masalah, kreatif, dan menghemat waktu sebab bisa belajar lebih cepat. Menurut Fatmawati (2016) dengan penerapan mind mapping mahasiswa mampu mengekpresikan ide kreatinya yang terdiri atas: kelancaran berpikir dan menciptakan banyak ide, menciptakan ide baru yang berbeda atau melihat dari sudut pandang lain, serta menciptakan jenis yang tidak biasa/tidak pernah ada sebelumnya. Karena manfaat-manfaat tersebut di atas, para guru perlu mengetahui cara mengajarkan teknik peta pikiran dan mengaitkan peta pikiran dalam pelajaran mereka. (Tee et al., 2014)

Langkah penerapan metode mind mapping dalam pembelajaran menurut DePorter (2001) yaitu sebagai berikut: 1) Kekuatan ambak, dosen memberi informasi tentang manfaat yang akan diperoleh setelah mempelajari materi, 2) Penataan lingkungan belajar, lingkungan belajar dibuat agar nyaman sehingga dapat membuat rileks pikiran serta bisa memberikan semangat untuk belajar, 3) Memupuk sikap juara, diberikan pujian pada mahasiswa yang telah dapat menyelesaikan tugas dengan baik, serta diberikan dorongan terhadap mahasiswa yang belum menyelesaikan tugas dengan baik. 4) Bebaskan gaya belajarnya, diberikan kebebasan kepada mahasiswa agar menentukan gaya belajar yang diinginkannya, 5) Membiasakan mencatat, mahasiswa meringkas materi yang diberikan oleh dosen, 6) Mebiasakan untuk membaca, mahasiswa menegaskan dan mengulang kembali materi yang sudah disampaikan, 7) Jadikan mahasiswa lebih kreatif, mahasiswa diberi kesempatan agar memecahkan masalah sesuai dengan yang telah dipahaminya, serta diberi soal yang harus diselesaikan secara estafet, 8) Melatih kekuatan memori, mahasiswa diberi soal secara bertahap agar dapat melatih ingatannya, dan 9) Rayakan, dosen 
memberikan penghargaan kepada mahasiswa. Untuk membuat mind mapping mahasiswa diminta agar mencari dan menggunakan referensi sebanyak mungkin dari buku ataupun jurnal penelitian (Zulyani, 2014). Metode mind mapping dipandang cocok digunakan agar dapat meningkatkan hasil belajar kognitif mahasiswa. Dengan mind mapping diharapkan mahasiswa tidak lagi mengalami kesulitan untuk memahami, menguasai, serta mengerti materi perkuliahan yang dipelajari (Sari, et al., 2020). Ferwati (2019) menjelaskan kelas yang menggunakan metode mind mapping memiliki nilai hasil belajar lebih baik dibanding kelas konvensional, hal ini juga di dukung oleh Monariska (2017) kelas yang memperoleh pembelajaran menggunakan metode mind mapping kemampuan pemahaman konsep terhadap mahasiswa lebih baik dibandingkan dengan mahasiswa yang memperoleh pembelajaran melalui metode konvensional. Menurut Hatchi dan Sari (2018) penerapan metode mind mapping juga dapat meningkatkan aktivitas belajar mahasiswa dengan ratarata siklus akhirnya mencapai $81,82 \%$. Melalui penggunaan metode mind mapping berbantuan e-learning hasil belajar mahasiswa mengalami peningkatan dilihat dari nilai rata-rata kognisi mahasiswa di siklus terakhir mencapai 86 (Widiyasari, 2017). Dari penelitian serupa yang dilakukan oleh Misidawati (2020) telah ditemukan metode mind mapping dapat meningkatkan hasil belajar pada 44 mahasiswa dengan ketuntasan di siklus dua mencapai $88 \%$.

Hasil belajar adalah pola-pola perbuatan, nilai-nilai, pengertian-pengertian, sikapsikap, apresiasi, dan keterampilan (Gagne dalam Thobroni, 2015). Selain itu, hasil belajar menurut Bloom mencakup kemampuan kognitif, afektif dan psikomotorik. Hasil belajar yang digunakan dalam penelitian ini adalah hasil belajar mahasiswa pada ranah kognitif. Revisi dari taxonomi Bloom pada ranah kognitif menurut Krathwohl (2002) mencakup mengingat, memahami, menerapkan, menganalisis, mengevaluasi, serta mencipta. Peneliti ingin menggunakan metode mind mapping berbasis daring untuk meningkatkan hasil belajar mahasiswa pada ranah kognitif di masa pandemi covid-19. Platform/aplikasi daring yang digunakan oleh peneliti dalam pembelajaran ialah menggunakan WhatsApp, Google Classroom, dan Zoom Meeting. Langkah/sintaks metode mind mapping dalam penelitian menggunakan langkah mind mapping menurut DePorter (2001) yang terdiri dari 9 langkah sesuai dengan penjelasan di paragraf sebelumnya. Adapun tujuan dari penelitian ini antara lain. 1) mendeskripsikan penerapan metode mind mapping pada mata kuliah Keterampilan Berbahasa Indonesia mahasiswa PGSD Universitas Nusa Cendana (UNDANA), 2) mendeskripsikan peningkatan hasil belajar mahasiswa pada ranah kognitif pada mata kuliah Keterampilan Berbahasa Indonesia mahasiswa PGSD UNDANA melalui penerapan metode mind mapping.

\section{Metode Penelitian}

Jenis penelitian yang digunakan ialah Penelitian Tindakan Kelas (PTK) dengan tahap pelaksanaannya merujuk pada model siklus PTK Kemmis dan Taggart dalam Akbar (2009) yang terdiri atas perencanaan, tindakan, observasi serta refleksi. Subjek PTK ini ialah mahasiswa semester 3 (tiga) kelas E program studi Pendidikan Guru Sekolah Dasar (PGSD) Universitas Nusa Cendana (UNDANA) sebanyak 48 orang. Jenis data yang diperoleh ialah hasil belajar kognitif mahasiswa di setiap siklusnya. Prosedur PTK dirancang untuk 2 siklus, siklus I serta siklus II, namun apabila masih belum ada kenaikan nilai/masih belum tercapai hasilnya sesuai dengan yang diharapkan maka akan dirancang sampai dengan siklus III. Siklus satu dilaksanakan dua kali pertemuan dan siklus dua juga 
dilaksanakan dua kali pertemuan perkuliahan. Pada penelitian ini siklus II merupakan pelaksanaan dengan perbaikan dari siklus pertama yang telah dilaksanakan. Data yang telah terkumpul akan dianalisis melalui cara kualitatif serta kuantitatif. Indikator keberhasilan penelitian ini yaitu melalui penerapan metode mind mapping berbasis daring terdapat adanya peningkatan hasil belajar kognitif mahasiswa semester 3 (tiga) kelas E PGSD Universitas Nusa Cendana UNDANA dalam mata kuliah Keterampilan Berbahasa Indonesia di masa pandemi Covid-19. Peningkatan hasil belajar kognitif setiap siklusnya mulai siklus I sampai siklus II dilihat dari kenaikan nilai rata-rata yang signifikan.

\section{Hasil Penelitian}

Kualitas pembelajaran dengan mengaplikasikan metode mind mapping berbasis daring pada mata kuliah Keterampilan Berbahasa Indonesia di masa pandemi Covid-19 untuk mahasiswa semester 3 kelas E PGSD Universitas Nusa Cendana akan dibahas berikut ini. Adapun pencapaian kualitasnya ialah analisis hasil tes ranah kognitif pada setiap siklusnya yaitu siklus I (satu) serta siklus II (dua). Pada siklus I (satu), berdasarkan atas tes hasil belajar pada ranah kognitif mahasiswa dengan jumlah 48 orang dikategorikan baik. Berikut dipaparkan rekap tes hasil belajar kognitif mahasiswa PGSD UNDANA pada mata kuliah Keterampilan Berbahasa Indonesia selama menggunakan metode mind mapping berbasis daring di masa pandemi covid-19 siklus I disajikan dalam tabel 1.

Tabel 1. Siklus I Nilai Hasil Belajar Kognitif Mahasiswa

\begin{tabular}{|c|c|c|c|c|c|c|}
\hline \multirow[t]{2}{*}{ Pertemuan } & \multirow{2}{*}{$\begin{array}{c}\text { Kategori } \\
\text { Nilai }\end{array}$} & \multirow[t]{2}{*}{ Frekuensi } & \multirow[t]{2}{*}{ Persentase } & \multirow[t]{2}{*}{ Keterangan } & \multicolumn{2}{|c|}{ Nilai Rata-rata Kelas } \\
\hline & & & & & $\begin{array}{c}\text { Tiap } \\
\text { Pertemuan }\end{array}$ & $\begin{array}{l}\text { Siklus } \\
\text { II }\end{array}$ \\
\hline \multirow{5}{*}{1} & $1-20$ & - & & Sangat Kurang & & \multirow{10}{*}{75,26} \\
\hline & $21-40$ & - & & Kurang & & \\
\hline & $41-60$ & 1 & $2,08 \%$ & Cukup & 75,21 & \\
\hline & $61-80$ & 43 & $89,59 \%$ & Baik & & \\
\hline & $81-100$ & 4 & $8,33 \%$ & Sangat Baik & & \\
\hline \multirow{5}{*}{2} & $1-20$ & - & & Sangat Kurang & \multirow{5}{*}{75,3} & \\
\hline & $21-40$ & - & & Kurang & & \\
\hline & $41-60$ & - & & Cukup & & \\
\hline & $61-80$ & 46 & $95,83 \%$ & Baik & & \\
\hline & $81-100$ & 2 & $4,17 \%$ & Sangat Baik & & \\
\hline
\end{tabular}

Dari Tabel 1 diatas diperoleh data hasil belajar kognitif pada mahasiswa semester 3 kelas E PGSD Universitas Nusa Cendana di siklus satu ini dalam dua pertemuan perkuliahan. Di pertemuan pertama terdapat 1 mahasiswa dengan kategori hasil belajar kognitifnya cukup dengan persentase $2,08 \%$, kategori hasil belajar kognitif baik mencapai 43 mahasiswa dengan persentase $89,59 \%$, serta dikategori sangat baik terdapat 4 mahasiswa dengan persentasenya yaitu $8,33 \%$. Rata-rata nilai hasil belajar di ranah kognitif mahasiswa siklus I pertemuan pertama ialah 75,21. Pada pertemuan kedua, hasil belajar kognitif mahasiswa yang berada pada kategori baik mencapai 46 mahasiswa dengan persentase $95,83 \%$, serta terdapat 2 mahasiswa yang kategori hasil belajar kognitifnya sangat baik dengan persentase $4,17 \%$. Rata-rata nilai hasil belajar di ranah kognitif mahasiswa pada siklus I pertemuan kedua tidak jauh berbeda dengan pertemuan pertama yaitu 75,3. Berdasarkan hasil tersebut diperoleh rata-rata nilai hasil belajar mahasiswa di ranah kognitifnya pada siklus I (satu) ialah sebesar 75,26 dengan kriteria baik. Pada siklus 
II (dua), berdasarkan atas tes hasil belajar pada ranah kognitif mahasiswa dengan jumlah 48 mahasiswa dikategorikan sangat baik. Berikut dipaparkan rekap tes hasil belajar kognitif mahasiswa PGSD UNDANA pada mata kuliah Keterampilan Berbahasa Indonesia selama menggunakan metode mind mapping berbasis daring di masa pandemi covid-19 siklus II disajikan dalam Tabel 2.

Tabel 2. Siklus II Nilai Hasil Belajar Kognitif Mahasiswa

\begin{tabular}{|c|c|c|c|c|c|c|}
\hline \multirow[t]{2}{*}{ Pertemuan } & \multirow{2}{*}{$\begin{array}{c}\text { Kategori } \\
\text { Nilai }\end{array}$} & \multirow[t]{2}{*}{ Frekuensi } & \multirow[t]{2}{*}{ Persentase } & \multirow[t]{2}{*}{ Keterangan } & \multicolumn{2}{|c|}{ Nilai Rata-rata Kelas } \\
\hline & & & & & $\begin{array}{c}\text { Tiap } \\
\text { Pertemuan }\end{array}$ & $\begin{array}{l}\text { Siklus } \\
\text { II }\end{array}$ \\
\hline \multirow{5}{*}{1} & $1-20$ & - & & Sangat Kurang & & \multirow{10}{*}{83} \\
\hline & $21-40$ & - & & Kurang & & \\
\hline & $41-60$ & - & & Cukup & 82,6 & \\
\hline & $61-80$ & 23 & $47,92 \%$ & Baik & & \\
\hline & $81-100$ & 25 & $52,08 \%$ & Sangat Baik & & \\
\hline \multirow{5}{*}{2} & $1-20$ & - & & Sangat Kurang & \multirow{5}{*}{83,4} & \\
\hline & $21-40$ & - & & Kurang & & \\
\hline & $41-60$ & - & & Cukup & & \\
\hline & $61-80$ & 10 & $20,83 \%$ & Baik & & \\
\hline & $81-100$ & 38 & $79,17 \%$ & Sangat Baik & & \\
\hline
\end{tabular}

Dari Tabel 2 diatas diperoleh data hasil belajar kognitif pada mahasiswa semester 3 kelas E PGSD Universitas Nusa Cendana di siklus dua ini dalam dua pertemuan perkuliahan. Di pertemuan pertama terdapat 23 mahasiswa dengan kategori hasil belajar kognitifnya baik dengan persentase $47,92 \%$, serta kategori hasil belajar kognitif sangat baik mencapai 23 mahasiswa dengan persentase 52,08\%. Rata-rata nilai hasil belajar mahasiswa di ranah kognitif siklus II pertemuan pertama ialah 82,6. Pada pertemuan kedua, hasil belajar kognitif mahasiswa yang berada pada kategori baik mencapai 10 mahasiswa dengan persentase $20,83 \%$, serta terdapat 38 mahasiswa yang kategori hasil belajar kognitifnya sangat baik dengan persentase 79,17\%. Rata-rata nilai hasil belajar mahasiswa di ranah kognitif pada siklus kedua pertemuan kedua yaitu 83,4. Berdasarkan hasil tersebut diperoleh rata-rata nilai hasil belajar mahasiswa di ranah kognitifnya pada siklus II (dua) ialah sebesar 83 dengan kriteria sangat baik.

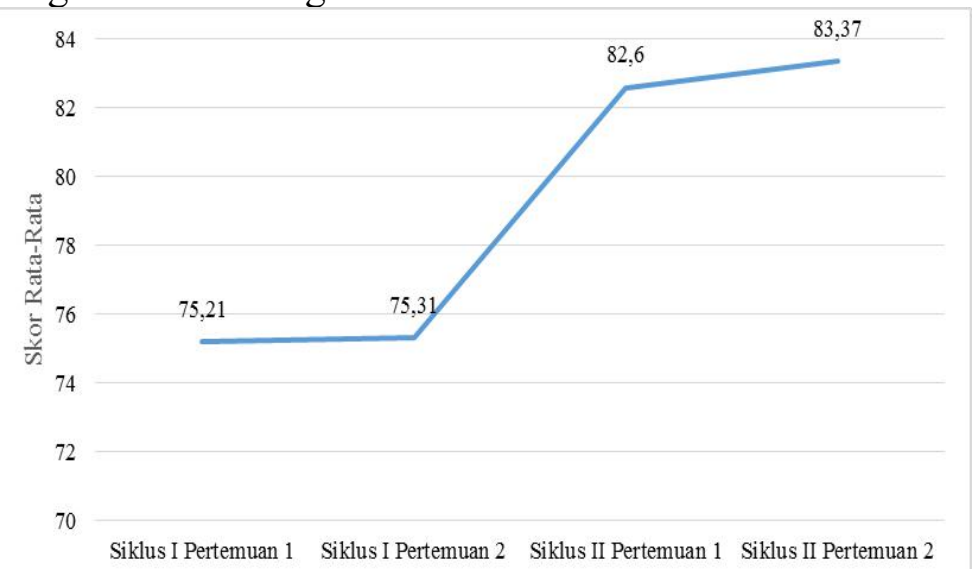

Gambar 1. Grafik Peningkatan Hasil Belajar Kognitif pada Setiap Siklus

Dari penelitian ini, ditemukan bahwa dengan mahasiswa membuat peta pikiran/mind mapping dapat membantu dan memudahkan mahasiswa dalam mengingat 
materi yang dipelajari, sehingga hasil belajar mahasiswa bisa meningkat. Dalam membuat mind mapping ini mahasiswa diminta untuk mencari referensi dari berbagai buku atau berbagai sumber sebanyak-banyaknya agar bisa menambah wawasan dari materi yang dipelajari. Di awal mahasiswa memang masih kesulitan dalam membuat mind map, namun dosen terus membimbing mahasiswa melalui Virtual Meeting Zoom, Google Classroom, Serta WhatsApp, hingga akhirnya mahasiswa dapat membuat mind mapping sesuai dengan materi dan referensi tambahan dari berbagai sumber buku baik offline maupun online.

Dalam proses pembuatan mind mapping itu sendiri, dalam penelitian ini dosen membebaskan mahasiswa membuat dengan cara manual, menggunakan software memanfaatkan teknologi, atau bisa mencari aplikasi di HP android yang dimilikinya masing-masing, hal ini disesuaikan juga dengan kondisi masing-masing dari mahasiswa di kelas IIIE PGSD UNDANA. Dosen juga membimbing mahasiswa agar dalam membuat peta pikiran/mind map untuk lebih kreatif baik dalam pembuatan secara manual ataupun dengan bantuan software/aplikasi di HP masing-masing. Setelah mahasiswa selesai dalam membuat mind map, dalam pertemuan Zoom Meeting mahasiswa secara bergantian diberi kesempatan untuk membagikan informasi kepada mahasiswa yang lain berdasarkan mind map yang telah dibuatnya. Kemudian mahasiswa yang lain bisa memberikan saran, tanggapan, serta pertanyaan, dari sini timbul diskusi yang aktif. Diakhir perkuliahan dosen memberikan apresiasi/pujian serta penguatan kepada semua semua mahasiswa, dan tidak lupa mengingatkan mahasiswa agar mengumpulkan mind map yang telah dibuat di Google Classroom kelas IIIE yang sudah dibuat sebelumnya.

\section{Pembahasan}

Untuk meningkatkan hasil belajar mahasiswa pada ranah kognitif digunakan metode mind mapping yang dikemukakan oleh DePorter (2001) yaitu sebagai berikut: 1) Kekuatan ambak, dosen memberi informasi tentang manfaat yang akan diperoleh setelah mempelajari materi, 2) Penataan lingkungan belajar, lingkungan belajar dibuat agar nyaman sehingga dapat membuat rileks pikiran serta bisa memberikan semangat untuk belajar, 3) Memupuk sikap juara, diberikan pujian pada mahasiswa yang telah dapat menyelesaikan tugas dengan baik, serta diberikan dorongan terhadap mahasiswa yang belum menyelesaikan tugas dengan baik. 4) Bebaskan gaya belajarnya, diberikan kebebasan kepada mahasiswa agar menentukan gaya belajar yang diinginkannya, 5) Membiasakan mencatat, mahasiswa meringkas materi yang diberikan oleh dosen, 6) Mebiasakan untuk membaca, mahasiswa menegaskan dan mengulang kembali materi yang sudah disampaikan, 7) Jadikan mahasiswa lebih kreatif, mahasiswa diberi kesempatan agar memecahkan masalah sesuai dengan yang telah dipahaminya, serta diberi soal yang harus diselesaikan secara estafet, 8) Melatih kekuatan memori, mahasiswa diberi soal secara bertahap agar dapat melatih ingatannya, dan 9) Rayakan, dosen memberikan penghargaan kepada mahasiswa.

Penerapan metode mind mapping pada mata kuliah Keterampilan Berbahasa Indonesia di kelas III E mahasiswa PGSD Universitas Nusa Cendana dilakukan dalam 2 siklus, masingmasing siklus terdiri dari 4 tahapan yaitu (1) perencanaan, (2) pelaksanaan dan pengamatan, (3) refleksi dan (4) perbaikan. Pada Satuan Acara Perkuliahan (SAP) siklus II, guru melakukan perbaikan dari siklus I dan terdapat peningkatan. Hasil pelaksanaan siklus I memberikan deskripsi bahwa proses dalam memfasilitasi mahasiswa untuk memperoleh hasil belajar secara optimal belum sesuai. Mind map yang telah dibuat oleh mahasiswa belum bisa membuat mahasiswa memperoleh pemahaman materi perkuliahan secara mandiri dengan 
baik. Hal ini terlihat dari kebiasaan mahasiswa yang masih sedikit dalam mencari referensi dari berbagai sumber untuk dibacanya, sehingga peran dosen diperlukan untuk meluruskan dan mengoreksi mind map yang telah dibuat oleh mahasiswa. Terkait faktor-faktor yang menyebabkan hasil belajar pada Siklus I kurang optimal, maka pada Siklus II dilakukan upaya-upaya sebagai berikut. 1) memberikan bimbingan lebih intensif kepada mahasiswa dalam menyelesaikan masalah, 2) memberikan motivasi lebih kepada mahasiswa dan menghubungkan materi dengan contoh-contoh yang relevan, 3) memberikan bantuan yang lebih banyak seperti ringkasan materi dari berbagai sumber. 4) membimbing mahasiswa dalam membuat mind mapping. 5) Mendorong mahasiswa untuk mengungkapkan masalahnya melalui lembar refleksi untuk didiskusikan bersama. Hasil pelaksanaan pembelajaran siklus II dengan menggunakan metode mind mapping sikap belajar mahasiswa sudah mulai berubah. Mahasiswa sudah mau mencari dan membaca buku referensi di awal pembelajaran, tingkat keterlibatan mahasiswa dalam mendiskusikan materi perkuliahanpun mulai meningkat. Sehingga hasil belajar mahasiswa pada ranah kognitifnya bisa meningkat pada siklus II ini. Penerapan metode mind mapping dapat meningkatkan hasil belajar mahasiswa pada ranah kognitifnya, hal ini juga didukung oleh pendapat Liu, Zhao, Ma, \& Bo (2014) bahwa mind mapping lebih membantu untuk meningkatkan prestasi akademik siswa dari pada prestasi afektif. Mungkin ada dua alasan untuk menjelaskannya. Pertama, peta pikiran adalah sejenis alat yang divisualisasikan dan sangat membantu dalam hal penyimpanan informasi yang sangat membantu untuk belajar dengan baik. Kedua, sebagian besar studi tentang mind mapping berasal dari China dan China lebih memperhatikan prestasi akademik siswa dan akan berusaha sebaik mungkin untuk meningkatkannya.

\section{Simpulan dan Saran}

Metode mind mapping berbasis daring pada mahasiswa semester 3 kelas E program studi Pendidikan Guru Sekolah Dasar Universitas Nusa Cendana di masa pandemi Covid19 dapat diterapkan dengan baik pada mata kuliah Keterampilan Berbahasa Indonesia. Kegiatan di setiap siklusnya telah terbukti bahwasanya dalam menerapkan metode mind mapping berbasis daring, dosen dapat memperbaiki permasalahan pembelajaran yang dihadapi. Secara keseluruhan penerapan metode mind mapping berbasis daring telah berhasil dan terlaksana dengan baik pada setiap langkahnya. Meskipun masih terdapat beberapa kendala/kekurangan, namun hal tersebut masih bisa diperbaiki di pertemuan pembelajaran atau siklus berikutnya. Hasil belajar mahasiswa pada ranah kognitif dapat ditingkatkan melalui penerapan metode mind mapping berbasis daring. Hal ini dapat terlihat dari hasil tes mahasiswa pada ranah kognitif di siklus I (satu) serta siklus II (dua), hasil belajar mahasiswa di ranah kognitif memperoleh rata-rata skor 75,26 dengan kategori baik di siklus pertamanya serta 83 di siklus kedua dikategorikan sangat baik.

Saran kepada pengajar ataupun peneti lain: (1) disarankan kepada pengajar untuk menggunakan metode mind mapping dalam upaya untuk meningkatkan hasil belajar siswa/mahasiswa pada ranah kognitif karena telah terbukti adanya peningkatan hasil belajar, (2) pengembangan lebih lanjut bagi peneliti dan pengajar yang ingin melakukan penelitian yang serupa disarankan untuk lebih memperhatikan sintaks/langkah metode mind mapping yang sesuai dengan karakteristik peserta didik.

\section{Daftar Rujukan}

Akbar, S. (2009). Penelitian Tindakan Kelas. Malang: Cipta Media Aksara. 
Astriani, D., Susilo, H., Suwono, H., Lukiati, B., \& Purnomo, A. R. (2020). Mind mapping in learning models: A tool to improve student metacognitive skills. International Journal of Emerging Technologies in Learning, 15(6), hal: 4-17. https://doi.org/10.3991/IJET.V15I06.12657.

Buzan, T. 2008. Buku Pintar Mind Map. Jakarta: PT Gramedia.

Buzan. T. (2004). Mind Map: Untuk Meningkatkan Kreativitas. Jakarta : Gramedia Pustaka Utama.

Darmuki, A., Hariyadi, A., dan Hidayati, N. A. (2020). Peningkatan Minat dan Hasil Belajar Keterampilan Berbicara Menggunakan Metode Mind Map pada Mahasiswa Kelas IA PBSI IKIP PGRI Bojonegoro Tahun Akademik 2019/2020. KREDO: Jurnal Penguatan Riset dan Pengembangan Kemenristekdikti RI, 3(2), hal: 263-276. https://doi.org/10.24176/kredo.v3i2.4687.

DePorter, B. (2000). Quantum Learning: Membiasakan Belajar Nyaman dan Menyenangkan. Bandung: Kaifa.

DePorter, B. (2001). Quantum Teaching: Mempraktikkan Quantum Learning di RuangRuang Kelas. Bandung: Kaifa..

Fatmawati, B. (2016). The analysis of students' creative thinking ability using mind map in biotechnology course. Jurnal Pendidikan IPA Indonesia, 5(2), hal: 216-221. https://doi.org/10.15294/jpii.v5i2.5825.

Ferwati, W. (2019). Pengaruh Penerapan Media Pembelajaran Mind Map Terhadap Hasil Belajar Mahasiswa pada Matakuliah Entomologi. Jurnal Pendidikan, Sains Agama dan Teknologi, 1(2), hal: https://ejurnal.univalabuhanbatu.ac.id/index.php/pena/article/view/91.

Hatchi, I. dan Sari, L. P. (2018). Penerapan Metode Mind Mapping Mata Kuliah Pengantar Pendidikan untuk Mahasiswa Semester I. Education Journal and Development Institut Pendidikan Tapanuli Selatan, 3(2), hal: 16-22. https://doi.org/10.37081/ed.v3i2.208.

Komar, N. dan Supriyono. (2010), Penerapan Model Pembelajaran Mind Mapping untuk Meningkatkan Minat dan Pemahaman Konsep Matematika. Hal: 57-61. http://ejournal.umpwr.ac.id/index.php/ekuivalen/article/download/3157/2970.

Krathwohl, D. R. (2002). A Revision of Bloom's Taxonomy: An Overview. Columbus, Ohio, Amerika Serikat: Ohio State University.

Liu, Y., Zhao, G., Ma, G., \& Bo, Y. (2014). The Effect of Mind Mapping on Teaching and Learning: Stand J.Edu.Res.Essay, 2(April), hal: 17-31. Diambil dari: https://scholar.google.com/scholar?start=30\&q=mind +mapping + journal\&hl=id\&as sdt $=0,5 \# \mathrm{~d}=\mathrm{gs}$ qabs $\& \mathrm{u}=\% 23 \mathrm{p} \% 3 \mathrm{D} 4 \mathrm{LWq} 7 \mathrm{lg} 8 \times \mathrm{mms}$.

Misidawati, D. N. (2020). Penerapan Metode Mind Mapping untuk Meningkatkan Pemahaman dan Hasil Belajar Mahasiswa dalam Mata Kuliah Manajemen Pemasaran di IAIN Pekalongan. LENTERA: Jurnal Ilmiah Kependidikan, 13(2), hal: 263-270. http://stkippgribl.ac.id/jurnal/index.php/lentera/article/view/648

Monariska, E. (2017). Penerapan Metode Mind Mapping untuk Meningkatkan Kemampuan Pemahaman Konsep Matematis Mahasiswa pada Mata Kuliah Kalkulus I. Jurnal PRISMA Universitas Suryakencana, (Online) 6(1), hal: 17-31. https://doi.org/10.35194/jp.v6i1.25.

Sabil, H. (2014). Meningkatkan Prestasi Belajar Melalui Model Mind Mapping pada Materi Lingkaran Mahasiswa Program Studi Pendidikan Matematika FKIP Universitas Jambi. Jurnal Edumatica, 4(2), hal: 31-38. 
https://www.neliti.com/publications/221049/meningkatkan-prestasi-belajar-melaluimodel-mind-mapping-pada-materi-lingkaran-m.

Sanjaya, W. (2006). Strategi Pembelajaran Berorientasi Standar Proses Pendidikan. Jakarta: Kencana.

Sari, L., Fandyansari, M. W., dan Sandiansyah, P. (2020). Mind Mapping dalam Perkuliahan Pengantar Pendidikan. Economic and Education Journal, 2(1), hal: 4960. Diambil dari: https://doi.org/10.33503/ecoducation.v2i1.771.

Siregar, R. (2014). Penggunaan Metode Mind Mapping terhadap Prestasi Belajar Siswa. Jurnal Pengabdian Kepada Masyarakat, 20(75), hal: 84-88. Diambil dari: https://doi.org/10.24114/jpkm.v20i75.4816.

Sudjana, N. (2005). Dasar-dasar Proses Belajar Mengajar. Bandung: Sinar Baru Algensindo.

Tee, T. K., Azman, M. N. A., Mohamed, S., Mohamad, M. M., Yunos, J., Yee, M. H., \& Othman, W. (2014). Buzan Mind Mapping: An Efficient Technique for. International Journal of Social, Behavioral, Educational, Economic, Business and Industrial Engineering, 8(1), hal: 28-31. Diambil dari: https://doi.org/10.5281/zenodo.1336202.

Thobroni, M. (2015). Belajar dan Pembelajaran Teori dan Praktik. Yogyakarta: AR-RUZZ MEDIA.

Widiyasari, R. (2017). Meningkatkan Aktivitas dan Hasil Belajar Mahasiswa Menggunakan Mind Map Berbantuan E-Learning Melalui Edmodo. Jurnal Teknodik, 21(1), hal: 27-43. Diambil dari: http://dx.doi.org/10.32550/teknodik.v21i1.270.

Zein, A. (2015). Penggunaan Mind Map dalam Meningkatkan Aktivitas dan Hasil Belajar Mahasiswa pada Mata Kuliah Biologi Umum di FMIPA Universitas Negeri Padang. Prosiding Semirata 2015 Bidang MIPA BKS-PTN Barat Universitas Tanjungpura Pontianak, hal: 482-491. Diambil dari: https://jurnal.untan.ac.id/index.php/semirata2015/article/view/13777.

Zuhaerini, dkk. (1977). Metode Khusus Pendidikan Agama Islam. Surabaya: Usaha Nasional.

Zulyani, R. (2014). Hubungan Antara Hasil Pembuatan Mind Mapping Mahasiswa dengan Hasil Belajar pada Materi Kromatografi Kertas. Jurnal Ilmiah DIDAKTIKA, 15(1), hal: 32-41. Diambil dari: http://dx.doi.org/10.22373/jid.v15i1.556. 